\title{
The lonely death of Aaron, the cowards at MIT.
}

\section{Camille Akmut}

In the tradition of topical songs, and the rightful right and obligation of academics to exercise critic and take position, we render here the life, and death of Aaron Swartz, reality and fiction altogether (a personal vision). In the tradition of satirical political observers of times, which are not ours, we accuse the many cowards that could never live up to their roles. 
Hattie Carroll was a maid in the kitchen. She was fifty-one years old and gave birth to ten children Who carried the dishes and took out the garbage And never sat once at the head of the table

Got killed by a blow, lay slain by a cane That sailed through the air and came down through the room, Doomed and determined to destroy all the gentle.

In the courtroom of honor, the judge pounded his gavel To show that all's equal and that the courts are on the level And that the strings in the books ain't pulled and persuaded And that even the nobles get properly handled (...) a six-month sentence.

(Bob Dylan, The Lonesome Death of Hattie Carroll) 


\section{Not Just a Song (A Song of Love)}

At Stanford, he had learned many lessons already on the cruelty of our world : brats with little to no culture beyond computer science, those that later became the cowboys of the computer and Web age... dumb as stones, cruel like quants. (And, many of them most likely became many of these things later on.)

Aaron wanted something else : everyone equal in front of information, not just books or articles for gentlemen of scholarly concerns and priorities.

Aaron - by all that we know - had a good home : a boy genius, the pride and light of his parents.

Parents who could barely speak, for fear they should cry, when hounded by journalists for answers no one had.

But, because he was smart, he must have also known that these were special circumstances : not everyone grew up rich like that.

With backgrounds like that he could have become many things : too frail to face the world, too much to loose to take risks, a normal decent life with children and all. He did none of those things.

And, he certainly did not become a Zanzinger, who even in old age showed no remorse.

(Our elites are not sorry : they are only sorry when caught. That is a big difference. "It's actually had no effect upon my life" claimed Zanzinger.

"Moral faults", and promises "to do better" say our new ones.)

And, so he chose to use his life, and lead his life, to do the most good he could, in the little time he had.

Better than most, for he did so much with so little. He had lived the equivalent of thousands of lives.

Did he know early on he would not live long?

As he grew, he grew up so fast, reading and consuming information at stupendous pace, knowledge ranging from mathematics (G. H. Hardy, D.J. Bernstein), computer science to economics (Keynes) and the parts of popular culture he enjoyed (Buffy in particular!).

Someone so smart was bound to become something, and that he did : speaking and working as equals with the great minds of his times : the good professor of 
law Lawrence Lessig, whom school had also taught much about the ways of our world early on, the inventor of the Web, Tim Berners-Lee, who envisioned his creation as way to further humanity, had it had any other inventor, things would have been very different for our Web we are sure, Paul Graham, who dislikes most of the humanities, but provided capital for our "applied sociologist".

Our boy has grown up. An adult now.

As an adult, and as time passed by, he never gave up, and if he did never for long, or lose integrity.

Made a million with a shrug of shoulders - or some pizza and cola.

But, with adulthood came many responsibilities, and many more lessons learned.

Bills, apartments to pay, electricity, food, mail, bank accounts, and all the combined, confining responsibilities of adulthood.

As to what money can bring : it is always little, while it takes a lot away.

The lawyer letters : that was later.

At Reddit, did Aaron spend a lot of time wishing he could be somewhere else, someone else? To avoid working. To avoid thinking.

The corporate place was one of the brutal lessons for him.

$\mathrm{He}$ - for whom thinking was an activity of first importance - couldn't think anymore, for no reason.

We will not philosophize about the cruelties of the workplace.

He went to Berlin.

The Berlin of Berthold Brecht, David Bowie, Grosz and his portraits of the underworld, that of Magnus Hirschfeld, queer solidarity and pride.

They fired him.

Fast-forward : it gets worse.

At MIT, he entered a closet.

In his life, he had never let himself be bounded by any : neither bounded by lim- 
its of disciplines, the boundaries of love, the instructions of computer manuals, restrictions of networks, proper knowledge for proper people, life paths...

Aaron did not distinguish between genders when it came to relationships, love or sex - were are not sure, any of these things. Perhaps, he did not, because other things mattered to him more. (The most important.)

"Skin is skin under the sheets".

Did he like Buffy and Angel - because contrary to other shows of the time like Friends - it featured the whole array of human experiences : heterosexual people, homosexual people, good demons, bad people (Wolfram and Hart)? Ghosts, singings hosts, dubious lawyer clients, lesbian women all of it.

Swartz connected the Acer laptop to MIT's computer network from a location in Building 16 at MIT ...

Swartz specified the computer's client name as "ghostlaptop." ... In this case, the "ghost" client name abridged the pseudonym "GaryHost" by combining the first initial "g" with the last name "host".

The cops was called.

At MIT, the cops were called in quickly : because he knew he had done nothing wrong, not by any standards of any sane society, he cooperated with a smile.

(Aaron, we think, most likely did not believe in God : there was nothing beyond. And, that was why he needed - and we all need - to do as much as he could we can - while he still could.)

He had done the hardest part : put the program together, lambda function and all, it all worked so good he downloaded more on some days than the entire network of MIT users (users described as "legal" in the legal documents while they keep stressing his foreign nature).

One of the lines in the program said "tenacious cookie".

Smarter than the smartest, more loving and lovable than most.

But, the hammer of our earthly justice came crashing down : campus cops, then the real cops, lawyers, the white letters from their offices, the lawyers from JSTOR, court appointments and the same fog started setting in - not being able to think, fears.

He lived in Massachusetts, what address did the letters bear. 
Meanwhile, on some other ends of the planet : middle-aged financiers responsible for crises from Washington to Paris do not belong in prison : schemes and worse galore, but if the color of their hearts were to be made that of their skins : theirs would be charcoal, black. Acquittals, acquittals, acquittals after acquittals, acquittals after acquittals, no shame none.

"Fear is the little death."

One day, that day :

Aaron, who was an angel, stepped on a chair and let himself fall, alone in his apartment. His vision twirled.

He did not want to burden anyone.

And, so died someone with a heart of a gold.

He was 26 years old.

His girlfriend came home, discovered him, there, lifeless, hanging upside down, and took him down, down from the ceiling. (in tears)

It was a mistake she must have thought, at first.

But, our world is a mistake, if the best of ours, have ends like that.

Now is the time for your tears. Fears he had none, he had already done so much. Others could build on what he had done. The work was done.

In the searches for answers, one may look in many places, but in the case of MIT one does need to look long : here is an institution - billions of dollars heavy with a name worth more than gold, but whose entire reputation is precisely based on the kind of people like Aaron. Who liked to think outside the box. Who liked to tinker. Who enjoyed making their contributions available to others. The "original" hackers. Who didn't care what anyone thought.

The makers of programs that make us dream : printers with functionalities they never should have had, never imagined by their makers, not documented in their manuals, not even in the black ones of engineers, computers that filled entire rooms suddenly made to play chess instead of calculating ballistic trajectories.

A reputation - temporary as we always like to write : a reputation it does not 
deserve. For certain honors, as the philosopher Jacques Bouveresse stressed, bring dishonor. (Who had himself refused a medal handed to him by a disreputable government.)

But, our boy stood alone.

And, he took it for so long as he could until he couldn't. Our boy fought.

What would it have cost them - nothing - to intervene - nothing - and send a strong message : "We stand by him." Nothing. And, nothing they did.

An MIT inquiry, conducted by MIT, about MIT, found the same : they had done nothing, wrong.

In the courtroom of honor, they are guilty. Courage is so damn infectious, but so is your cowardice.

We must distance ourselves from those who long ago gave up, if they even tried. We make a big detour around MIT square. The little people in their tweed costumes too big for them, brains too little. We piss on them, bleed on cotton.

They were cowards already back then with bunnie. They were cowards again in the case of the student of the MIT Media Lab who made colorful clothes, full of lights, arrested at an airport.

Pranks they had played, the MIT students back in the days : false bomb jokes in the old days were pardoned, but boy had things changed.

A change no doubt codependent with the changing nature of their administrators and administrations (the old boys from Wall Street are now leading universities).

Medgar Evers received the burial of a king. Aaron Swartz' end created thousands more like him : smart as everything, the same wish to change our society.

When someone hangs themselves, does it mean they could not breath for a long time already? Only materializing what they felt for so long already.

The only thing true in USA v. Swartz :

No one wants to be "affiliated with MIT as a student, faculty member, or employee or in any other manner." (page 3)

And, the cowards at Jstor. And, the cowards at Jstor (ITHAKA HARBORS INC).

Aaron Swartz was someone who had done everything right. 
In the heaven of golden hearts, he is a hero - but down here too.

Now is not a time for tears, but anger. 